\title{
Screwed and cement implant prosthesis: current clinical considerations
}

\author{
Prótese sobre implante cimentada e parafusada: \\ considerações clínicas atuais
}

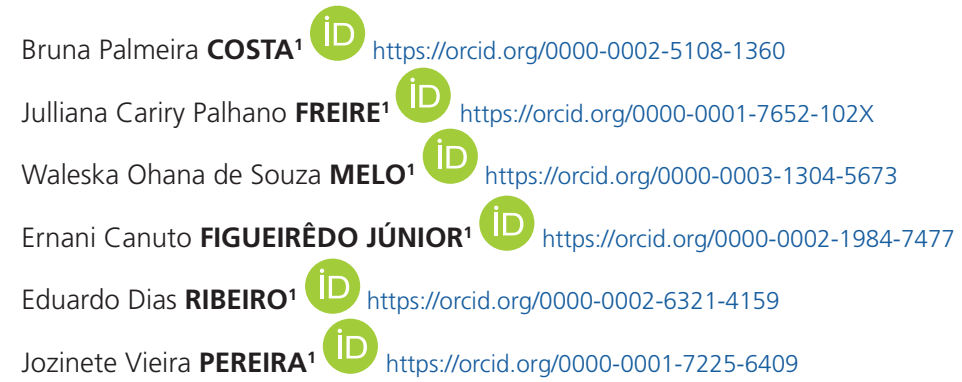

\section{ABSTRACT}

Introduction: There is no consensus as to which cemented or screwed retention system is best to avoid bone loss around the implant from a fixed implant-supported restoration. Objective: To evaluate the prosthesis retention systems on screw and cemented implants, regarding: bone loss, survival and failure rate, biological complications and microbiological analysis. Methods: A search was made for scientific articles that contemplated the subject through the databases Pubmed and SciELO, without period restriction. The titles, abstracts and then access to the full text has been verified. Results: It was found that excess cement may play an important role in the development of peri-implant disease. Technical failures are most seen in prosthesis retained by screws, and biological complications in cemented crowns. The success rate for both restraint systems is high, and retention-independent implant prosthesis treatment provides predictability. Conclusion: The appropriate retention system for the patient depends on several factors, including indication, advantages and disadvantages, retention provided, aesthetics and clinical performance.

Indexing terms: Dental implants. Dental prosthesis, implant-supported. Dental prosthesis retention. Dental prosthesis design.

\section{RESUMO}

Introdução: Não há consenso sobre qual sistema de retenção, cimentado ou parafusado, é o melhor para evitar perda óssea ao redor do implante de uma restauração fixa implanto-suportada. Objetivo: Avaliar os sistemas de retenção de próteses sobre implantes parafusadas e cimentadas, quanto aos fatores: perda óssea, taxa de sobrevivência e de falhas, complicações biológicas e análises microbiológicas. Métodos: Foi realizada uma busca por artigos científicos que contemplassem o tema através das bases de dados Pubmed e SciELO, sem restrição de período. Os títulos, resumos e em seguida o acesso ao texto completo foi verificado. Resultados: Foi observado que o excesso de cimento pode desempenhar um papel importante no desenvolvimento da doença peri-implantar. Falhas

$\boldsymbol{v} \mathbf{v} \boldsymbol{v}$

1 Universidade Estadual da Paraíba, Centro de Ciências Biológicas e da Saúde, Programa de Pós-Graduação em Odontologia. Rua Baraúnas, 351, Universitário, 58429-500, Campina Grande, PB, Brasil. Correspondence to: JCP FREIRE. E-mail: <jullianapalhano@hotmail.com>.

$\boldsymbol{\nabla} \mathbf{v} \boldsymbol{\nabla}$

How to cite this article

Costa BP, Freire JCP, Melo WOS, Figueirêdo Júnior EC, Ribeiro ED, Pereira JV. Screwed and cement implant prosthesis: current clinical considerations. RGO, Rev Gaúch Odontol. 2021;69:e20210057. http://dx.doi.org/10.1590/1981-863720210005720200082 
técnicas são mais observadas em próteses retidas por parafusos e complicações biológicas em coroas cimentadas. A taxa de sucesso para os dois sistemas de retenção é alta e o tratamento com próteses sobre implantes independente da retenção oferece previsibilidade ao caso. Conclusão: O sistema de retenção apropriado para o paciente depende de diversos fatores, incluindo a indicação, vantagens e desvantagens, retenção fornecida, estética e desempenho clínico.

Termos de indexação: Implantes dentários. Prótese fixa sobre implante. Retenção em prótese dentária. Planejamento de prótese dentária.

\section{INTRODUCTION}

Implant-supported fixed dental prostheses represent a well-established treatment option that has evolved to become a standard of care in dentistry in recent decades. Osseointegration has advanced through progress in implant surface technology, refining surgical techniques, improved interface stability between implants, abutments and dental prostheses [1]. Implant prosthesis survival rate is high [2-5].

A fixed dental prosthesis can be attached to an endosseous implant via cementation (using a temporary or definitive cement) on an implant abutment that is screwed to the implant, or directly into the implant via screw retention. The clinical decision as to which patient restraint system best fits depends on several factors. These factors include individual indication, advantages and disadvantages of different retention mechanisms, aesthetics and clinical performance, including failures and complications. The decision may depend on the technical feasibility [1].

Biological complication rates such as bone loss have been more frequently reported in cemented prostheses, while screwed ones have more technical complications $[1,6]$. A current meta-analysis indicated that cemented fixed prostheses showed less marginal bone loss than screwed prostheses. However, the small difference between the mean values may not show clinical significance [7]. There is no consensus on which retention system, cemented or screwed, is best for preventing bone loss around the implant.

Thus, the present literature review compared prosthetic retention systems on screwed and cemented implants. The following factors were analyzed: bone loss, survival and failure rate, biological complications and microbiological analyzes.

\section{METHODS}

We conducted a literature review based on research of scientific articles obtained from the databases:
Pubmed and SciELO, with the following keywords: Dental Implants, Implant-supported dental prosthesis, Dental Retention, dental design.

Studies comparing cemented and screw-retained fixed crown retention systems on implants and including factors such as bone loss, survival and failure rate, biological complications and microbiological analyzes were included. There was no period restriction for the search. Scientific articles that did not fit the proposed theme and inclusion criteria were excluded. The search process was performed in three phases through title search, abstract analysis and identification of full text articles.

Were obtained 9.892 two studies through the search strategy with the descriptors. After selection according to the inclusion criteria, ten scientific articles were selected for the present literature review.

\section{RESULTS AND DISCUSSION}

The scientific studies included in this literature review are shown in the Table 1.

In a retrospective clinical study, short implants that supported a unitary crown in the premolar region were selected. Fifty-one crowns were cemented and 77 were retained by screw. No failure events were recorded for implants and prostheses. Distal marginal bone loss was significantly lower in screw-retained crowns than in cemented crowns. Marginal bone loss $\geq 2 \mathrm{~mm}$ as a biological complication was more frequent in cemented crowns. Two screw loosening events were observed in screwed restorations. These events were resolved by screw readjustment [6].

Patients with two to three implants containing cemented or screwed restorations and five years of followup were selected for microbiological analysis in the periimplant grooves. The final sample consisted of 18 patients (55 implants) in the cemented group and 22 patients (46 implants) in the screwed group. Regarding the prevalence of positive bacterial sites, significant differences between 
Table 1. Scientific studies on screw and cemented implant prostheses.

\begin{tabular}{lccl}
\hline Author/year & \multicolumn{1}{c}{ Type of studie } & Objective & \multicolumn{1}{c}{ Sample } \\
\hline $\begin{array}{l}\text { Anitua \& Alkhraisat } \\
\text { [6] }\end{array}$ & Retrospective clinical study & Observing marginal bone loss & $\begin{array}{l}\text { Short implants in the } \\
\text { premolar region }\end{array}$ \\
\hline $\begin{array}{l}\text { Penarrocha-Oltra } \\
\text { et al. [8] }\end{array}$ & Retrospective clinical study & $\begin{array}{l}\text { Verifying } \\
\text { colonization in cemented and } \\
\text { screwed prostheses }\end{array}$ & $\begin{array}{l}55 \text { cemented and } 46 \\
\text { screwed prostheses }\end{array}$ \\
\hline Anchieta et al. [2] & Retrospective clinical study & $\begin{array}{l}\text { To evaluate the probability of } \\
\text { survival of fixed prostheses } \\
\text { on cemented and screwed hexagon connection } \\
\text { implants of three units }\end{array}$ \\
\hline
\end{tabular}

Identify the influence of the type of fixed prosthesis on

Millen et al. [9] Systematic review with meta- the rates of biological and analysis technical complications in the context of screw retention versus cement retention
The distal marginal bone loss was less in the screwed crowns than in the cemented ones. Marginal bone loss $\geq 2 \mathrm{~mm}$ was more frequent in cemented crowns.

Cemented prostheses had significantly higher bacterial loads in the peri-implant groove, but with significantly lower bacterial loads in the inner portion of the implant connection

The cemented groups had a higher probability of survival than the screwed groups.

Screwed prostheses showed a tendency towards significantly more technical complications than cemented prostheses with single crowns and fixed partial prostheses. Full-arch prostheses, cantilever prostheses and "all fixed prostheses" had significantly higher complication rates than single crowns

Observe the survival and Crespi et al. Eight-year follow-up clinical success of restorations with [3] survey screwed and cemented Screwed and cemented implants prosthetic structures.

The survival rate was $99.27 \%$. The two groups did not show statistically significant differences in bone loss

Evaluate survival results Screwed and cemented and complications of fixed reconstructions screwed and cemented fixed supported on dental reconstructions implants

Screwed reconstructions showed less technical and biological complications in general.

There was no evidence of a significant difference in the clinical behavior of periimplant marginal bone or peri-implant soft tissue between groups

There was no evidence of a significant difference in the clinical behavior of periimplant marginal bone or peri-implant soft tissue between groups.

Screwed crowns showed microcracks at the level of occlusal access to the screw Obtain the fracture resistance single screwed and and extensive fractures throughout the of screwed and cemented cemented porcelain thickness of the ceramic. Cemented single porcelain crowns. crowns
Cemented and screwed by implants single crowns retained tissues controlled trial of peri-implant margina Nissan et al. [11] In vitro studie

single porcelain crowns.
restorations were affected by less extensive paramarginal fractures of porcelain.

There was no evidence of behavior

Compare cemented and

Vigolo et al. [13]
Prospective, controlled clinical study screwed single crowns over implants for 4 years after prosthetic rehabilitation
Cemented and screwed single crowns over implants different from peri-implant marginal bone and peri-implant soft tissue when cemented or screwed unitary restorations on implants were provided 
groups were found only for Tannerella forsythia, 8.7 times more frequent in the peri-implant grooves of cemented than screwed prostheses. The contamination index values showed higher permeability to most microbes in the cemented group. Differences were found between the two prosthetic retention methods: the cemented group had significantly higher bacterial loads in the peri-implant sulcus, but with significantly lower bacterial loads in the internal portion of the implant connection [8].

Anchieta et al. [2] evaluated the probability of survival of cemented and screwed three-unit fixed implant prostheses using regular versus switching platforms). One hundred and sixty-eight implants with hexagon internal connection were selected for this study according to the horizontal implant/abutment configuration and retention method and divided into four groups: cemented regular platform; or retained by screw; cemented switching platform; or screwed. Cemented groups had a higher probability of survival than screwed groups. The survival probability of the cemented group was higher than the screwed one, regardless of the horizontal implantabutment configuration [2].

In a systematic review with meta-analysis, Millen et al. [9] identified the influence of the fixed prosthesis type on the rates of biological and technical complications in the context of screw retention versus cement retention. Screwed prostheses showed a tendency to significantly more technical complications than cemented prostheses with single crowns and fixed partial prostheses. For "all fixed prostheses" (unreported or unknown type of prosthesis), significantly fewer biological and technical complications with screw retention were observed. Multivariate analysis revealed a significantly higher incidence of technical complications with cemented prostheses. Full arch prostheses, cantilever prostheses and "all fixed prostheses" had significantly higher complication rates than single crowns [9].

In an eight-year follow-up clinical study, the survival and success of restorations with immediately loaded screwed and cemented implants were observed. Patients who were scheduled for full arch ceramic restorations were randomly divided into two groups: in one group, prosthetic structures were screwed into implants, and in the second group, the structures were cemented into abutments. After an 8-year follow-up period, a survival rate of $99.27 \%$ was reported for all implants. Final cemented and screwed ceramic restorations are highly predictable, biocompatible and aesthetically pleasing, and the two groups did not show statistically significant differences in bone loss [3].

An electronic database survey to evaluate survival outcomes and reported complications of screw-fixed and cemented fixed dental implant reconstructions found no statistical difference between reconstructions for survival or failure rates. Screwed reconstructions presented fewer technical and biological complications in general. There were no statistically significant differences between failure rates of different types of reconstruction or abutment materials (titanium, gold, ceramic). The failure rate of cemented reconstructions was not influenced by the choice of a specific cement, although the type of cement influenced the retention loss [5].

In a 10-year randomized controlled trial, Vigolo et al. [10] compared the long-term clinical outcome of implant-retained cemented and screwed unit crowns; the sample consisted of eighteen patients. The results indicated that there was no evidence of a significant difference in the clinical behavior of peri-implant marginal bone or peri-implant soft tissue between implant restorations of cemented or screwed single teeth.

To compare the long-term outcome and complications of cemented versus screw-retained implant restorations in partially edentulous patients, followup (up to 15 years) and examinations were performed every 6 months in the first year and every 12 months in the subsequent years. The following parameters were evaluated and recorded at each visit: ceramic fracture, abutment screw loosening, metal frame fracture, gingival index, and marginal bone loss. Ceramic fracture was significantly higher in screwed restorations $(38 \% \pm 0.3 \%)$ than in cemented restorations $(4 \% \pm 0.1 \%)$. Loosening of the abutment screw was statistically more frequent in screwed restorations $(32 \% \pm 0.3 \%)$ than in cemented restorations $(9 \% \pm 0.2 \%)$. There were no metal structure fractures in any type of restoration. The mean Gingival Index scores were statistically higher for screwed restorations $(0.48 \pm 0.5)$ than for cemented restorations. The long-term outcome of implant-supported cemented restorations was superior to that of both clinically and biologically screwed restorations [10].

Zarone et al. [12] evaluated in vitro the fracture resistance of screwed and cemented porcelain unit crowns. Screwed crowns showed microcracks at the occlusal access to the screw and extensive fractures across the thickness 
of the ceramic. Cemented restorations were affected by smaller porcelain paramarginal fractures. A stronger implant-prosthetic connection was noted in the group of cemented restorations than in screw-retained single crowns.

Vigolo et al. [13] conducted a prospective controlled clinical study to compare cemented and screwed implant crowns for 4 years after prosthetic rehabilitation. Periimplant marginal bone levels, peri-implant soft tissue parameters and prosthetic complications were verified. All 24 implants survived, resulting in a cumulative implant success rate of $100 \%$. Statistical analysis did not reveal significant differences between the two groups regarding peri-implant marginal bone levels and soft tissue parameters. The data obtained from this study suggested that the choice of cementation versus screw retention for single-tooth implant restorations is probably not based on clinical outcomes, but seems to be based primarily on clinician preference. results indicate that there was no evidence of different behavior of peri-implant marginal bone and peri-implant soft tissue when cemented or screwed unitary restorations were provided for this patient population [11].

Survival rate is high according to studies analyzed $[2,3,5,11]$. The choice of retention type (cemented or retained screw) may not have a crucial influence on overall prosthesis survival, but may be responsible for the development of a complication [1].

Biological complication rates (bone loss> $2 \mathrm{~mm}$ ) were higher in cemented prostheses, while screwed ones had more technical complications $[1,8]$. In contrast, some research has not found significant differences in bone loss for different types of retention $[3,4,11]$.

While the cemented group had significantly higher bacterial loads in the peri-implant sulcus in the study by Penarocha-Oltra et al. [8] and Nissan et al. [11] observed a higher gingival index in screw-retained prostheses. Cement remnants pose a significant risk of peri-implant infection and should be removed. The presence of excess cement plays an important role in the development of peri-implant disease [4]. In the development of a biological complication, host factors and biological interactions with the materials used play an important role $[12,13]$.

Unsealed reconstructions - in the event of a prosthesis adjustment error or excess cement - can cause a micro-gap and a small gap between the abutment and structure providing an anaerobic system for biofilm growth [14].

The results of this literature review corroborate that screw-retained prostheses have a higher rate of ceramic fractures than cemented ones $[10,15]$.

Parametric analysis with finite element evaluation of cemented and screwed prosthesis-implant connections provides a biomechanical and engineering comparison between two different types of implant-supported prostheses, concluding that a screw-implanted prosthesis appears to be less durable and tends to fracture more than a cemented prosthesis. As with other types of dental implants, the screwed connection appears to be the weak link in the chain, resulting in fatigue-related values and consequent prosthesis failure. In fact, thanks to their surface uniformity, cemented retained dentures offer a better and more homogeneous distribution of load forces compared to screwed prostheses [16].

Ceramic fracture is most likely in screw-retained dental prostheses. The presence of an access opening for a pillar screw disrupts the integrity of the structure, tension can be produced during tightening of the assembly. Manipulations with a screwdriver can cause stress peaks laterally in the access opening region. Resin fracture has been seen especially in total fixed dentures. Screw retention is advantageous in the case of a technical complication as it can be repaired more easily compared to cement retention. Technical complications are more reported in cemented than screwed prostheses according to the selected studies $[5,9]$.

An important clinical decision remains the choice of the type of connection - cement or retained screw. This connection may have an impact on the prognosis of general reconstruction. Which retention system is appropriate for the patient depends on a number of factors including indication, advantages and disadvantages, 'retention' provided, aesthetics and clinical performance (failures and complications) [1].

\section{CONCLUSIONS}

It has been found that excess cement may play an important role in the development of peri-implant disease. Technical failures are more commonly observed in screwretained prostheses and biological complications in cemented crowns. The success rate for both retention 
systems is high, and retention-independent implant prosthesis treatment provides case predictability. Professionals need to be aware of the individual clinical characteristics of each case when choosing this system.

\section{Collaborators}

BP COSTA and JCP FREIRE participated in the elaboration of the work, in the conception of the theme and in the writing. WOS MELO and EC FIGUEIRÊDO JÚNIOR participated in the scientific search of the articles and in the selection of researches for the literature review. ED RIBEIRO and JV PEREIRA guided and corrected the work.

\section{REFERENCES}

1. Wittneben J-G, Joda T, Weber H-P, Brägger U. Screw retained vs. cement retained implant-supported fixed dental prosthesis. Periodontol 2000. 2017;73(1):141-51.

2. Anchieta RB, Machado LS, Hirata R, Bonfante EA, Coelho PG. Platform-Switching for Cemented Versus Screwed Fixed Dental Prostheses: Reliability and Failure Modes: An In Vitro Study. Clin Implant Dent Relat Res. 2016;18(4):830-9.

3. Crespi R, Capparè P, Gastaldi G, Gherlone E. Immediate Occlusal Loading of Full-Arch Rehabilitations: Screw-Retained Versus Cement-Retained Prosthesis. An 8-Year Clinical Evaluation. Int J Oral Maxillofac Implants. 2014;29(6):1406-11.

4. Vigolo P, Givani A, Majzoub Z, Cordioli G. A 4-Year Prospective Study to Assess Peri-Implant Hard and Soft Tissues Adjacent to Titanium Versus Gold-Alloy Abutments in Cemented Single Implant Crowns. J Prosthodont. 2006;15(4):250-6.

5. Wittneben J-G, Millen C, Brägger U. Clinical Performance of Screw- Versus Cement-Retained Fixed Implant-Supported Reconstructions - A Systematic Review. Int J Oral Maxillofac Implants. 2014;29(Supplement):84-98.

6. Anitua E, Alkhraisat M. Clinical Performance of Short Dental Implants Supporting Single Crown Restoration in the MolarPremolar Region: Cement Versus Screw Retention. Int J Oral Maxillofac Implants. 2019;34(4):969-976.
7. Lemos CAA, de Souza Batista VE, Almeida DA de F, Santiago Júnior JF, Verri FR, Pellizzer EP. Evaluation of cement-retained versus screw-retained implant-supported restorations for marginal bone loss. J Prosthet Dent. 2016;115(4):419-27.

8. Penarrocha-Oltra D, Monreal-Bello A, Penarrocha-Diago M, Alonso-Perez-Barquero J, Botticelli D, Canullo L. Microbial Colonization of the Peri-Implant Sulcus and Implant Connection of Implants Restored With Cemented Versus Screw-Retained Superstructures: A Cross-Sectional Study. J Periodontol. 2016;87(9):1002-11.

9. Millen C, Brägger U, Wittneben J-G. Influence of Prosthesis Type and Retention Mechanism on Complications with Fixed Implant-Supported Prostheses: A Systematic Review Applying Multivariate Analyses. Int J Oral Maxillofac Implants. 2015;30(1):110-24.

10. Nissan J, Narobai D, Gross O, Ghelfan O, Chaushu G. Longterm outcome of cemented versus screw-retained implantsupported partial restorations. Int J Oral Maxillofac Implants. 2011;26(5):1102-7.

11. Vigolo P, Givani A, Majzoub Z, Cordioli G. Cemented versus screw-retained implant-supported single-tooth crowns: a 4-year prospective clinical study. Int J Oral Maxillofac Implants. 2004;19(2):260-5.

12. Derks J, Schaller D, Håkansson J, Wennström JL, Tomasi C, Berglundh T. Effectiveness of Implant Therapy Analyzed in a Swedish Population. J Dent Res. 2016;95(1):43-9.

13. Linkevicius T, Puisys A, Vindasiute $E$, Linkeviciene L, Apse P. Does residual cement around implant-supported restorations cause peri-implant disease? A retrospective case analysis. Clin Oral Implants Res. 2012;24(11):1-6.

14. Keller W, Brägger U, Mombelli A. Peri-implant microflora of implants with cemented and screw retained suprastructures. Clin Oral Implants Res. 1998;9(4):209-17.

15. Zarone F, Sorrentino R, Traini T, Di lorio D, Caputi S. Fracture resistance of implant-supported screw- versus cementretained porcelain fused to metal single crowns: SEM fractographic analysis. Dent Mater. 2007;23(3):296-301.

16. Cicciu M, Bramanti E, Matacena G, Guglielmino E, Risitano G. FEM evaluation of cemented-retained versus screw-retained dental implant single-tooth crown prosthesis. Int J Clin Exp Med. 2014;7(4):817-25.

Received on: 30/5/2020

Final version resubmitted on: 29/9/2020 Approved on: 15/10/2020 